\title{
Feedback regulation and the intracellular protein profile of Streptomyces griseus in a cycloheximide fermentation
}

\author{
Kevin H. Dykstra* and Henry Y. Wang \\ Department of Chemical of Engineering, University of Michigan, Ann Arbor, MI 48 109, USA
}

Received 12 February 1990/Accepted 26 June 1990

\begin{abstract}
Summary. Two-dimensional gel electrophoresis (2-D PAGE) was used to study the intracellular protein profile of Streptomyces griseus in relation to cycloheximide $(\mathrm{CH})$ biosynthesis. Four proteins (CR1-CR4) were found to be significantly and specifically repressed by addition of the antibiotic $(1 \mathrm{~g} / \mathrm{l}$ at $72 \mathrm{~h}$ ) to a producing fermentation. Synthesis of these proteins was specific to the idiophase, concurrent with $\mathrm{CH}$ production. Initial addition of $\mathrm{CH}$ to the production medium resulted in slightly lower synthesis rates of two of the proteins (CR1 and CR2), while significantly delaying the onset of synthesis of the other two (CR3 and CR4). Finally, neutral polymeric resin was added to the fermentation to alleviate feedback regulation of $\mathrm{CH}$ synthesis, giving roughly a twofold increase in the antibiotic production rate. Production of proteins CR3 and CR4 was increased approximately tenfold immediately following resin addition, but returned to the control rate of synthesis after $24 \mathrm{~h}$.
\end{abstract}

\section{Introduction}

The production of cycloheximide $(\mathrm{CH})$ by Streptomyces griseus is typical of many antibiotic fermentations. The desired product is formed only following the cell growth phase, probably in response to nutrient depletion (Payne and Wang 1988). The production of $\mathrm{CH}$ is closely linked to the consumption of carbon substrate (here, glucose), with accumulation ceasing almost immediately after depletion of reducing sugar in the medium (Kominek 1975a). The $\mathrm{CH}$ is also degraded during the fermentation, and there is evidence for both chemical (alkiline hydrolysis) and enzymatic mechanisms for its degradation (Payne 1984). Relatively little is known about its biosynthetic pathway (Vanek et al.

\footnotetext{
* Present address: Biomedical Engineering and Instrumentation Branch, National Institutes of Health, Building 13, Room 3W13, Bethesda, MD 20892, USA
}

Offprint requests to: $\mathrm{H}$. Y. Wang
1964), although its synthesis is subject to feedback regulation (Kominek 1975a, Payne and Wang 1989). Addition of $\mathrm{CH}$ to a producing fermentation has been shown to stop further accumulation of the antibiotic. Furthermore, in fed-batch fermentations, $\mathrm{CH}$ accumulates to a steady-state level (around $1 \mathrm{mg} / \mathrm{ml}$ ), and is then maintained at that maximum level. It has been suggested that this regulation occurs via feedback inhibition, i.e. that $\mathrm{CH}$ decreases the activity of its own biosynthetic enzyme system (Kominek 1975a). Feedback regulation and product degradation can be alleviated by maintaining the broth concentration of $\mathrm{CH}$ at a low level. Continuous removal of the antibiotic from the broth has been accomplishing using dialysis extraction fermentation (Kominek 1975b), and by addition of neutral polymeric resin to which the $\mathrm{CH}$ adsorbs (Wang 1983; Payne and Wang 1989). Application of these techniques results in substantial increases in both the rate and overall amount of $\mathrm{CH}$ produced. Here, we were interested in learning about the mode of feedback regulation and the effects of continuous product removal on the cells without finding the specific enzymes and intermediates in the pathway leading to $\mathrm{CH}$.

Two-dimensional polyacrylamide gel electrophoresis (2-D PAGE) is an extremely general and powerful technique for separating and visualizing complex protein mixtures, such as whole-cell extracts. It has been used, for example, to study heat shock and catalogue the proteins in Escherichia coli (Neidhardt and VanBogelen 1987), to examine mutation rates in the human genome (Neel et al. 1984), and to study intracellular protein changes due to disease (Goldman et al. 1982). However, it has not been extensively used in the study of secondary metabolism. In this work, we have used 2-D PAGE to find specific changes in the protein profile of $S$. griseus and relate them to the rate of $\mathrm{CH}$ synthesis.

\section{Materials and methods}

Strain and culture media. S. griseus strain UC-2132 obtained from Upjohn Corp. (Kalamazoo, Mich., USA) was used in these stud- 
ies. Cultures were maintained on agar slants containing glucose, $10 \mathrm{~g}$; Torula yeast, $10 \mathrm{~g}$; distiller solubles, $5 \mathrm{~g}$; $\mathrm{KCl}, 4 \mathrm{~g}$; $\mathrm{CaCO}_{3}$, $1 \mathrm{~g}$; agar (Difco, Detroit, Mich., USA) $15 \mathrm{~g}$, and tap water to 11 (Kominek 1975a). Inoculation of seed cultures was carried out by first adding $5 \mathrm{ml}$ sterile distilled water to a slant, and scraping off the spores. Seed medium ( $50 \mathrm{ml}$ in a $500-\mathrm{ml}$ flask) containing glucose, $10 \mathrm{~g}$; beef extract, $5 \mathrm{~g}$; peptone, $5 \mathrm{~g}$; NaCl, $5 \mathrm{~g}$; tap water, to 11 was then inoculated with $1 \mathrm{ml}$ of the spore solution, and incubated on a rotary shaker $(\sim 300 \mathrm{rpm})$ for 2 days at $25^{\circ} \mathrm{C}$. Production medium (Cerelose, $60 \mathrm{~g}$; defatted soy flour, $15 \mathrm{~g}$; Torula yeast, $2.5 \mathrm{~g}$; $\left(\mathrm{NH}_{4}\right)_{2} \mathrm{SO}_{4}, 5 \mathrm{~g} ; \mathrm{NaCl}, 4 \mathrm{~g} ; \mathrm{KH}_{2} \mathrm{PO}_{4}, 0.2 \mathrm{~g} ; \mathrm{CaCO}_{3}$ for $\mathrm{pH}$ control, $8 \mathrm{~g}$; and tap water to $1 \mathrm{l}$ ) (Kominek 1975a) was then inoculated with seed culture ( $10 \%$ of final fermentation volume) to start a fermentation experiment.
Fermentation and sampling methods. Shake flask fermentations were carried out in 500-ml erlenmeyer flasks $(50 \mathrm{ml}$ liquid volume) on a rotary shaker $(\sim 300 \mathrm{rpm})$ at $25^{\circ} \mathrm{C}$. In these experiments, two identical shake-flask cultures were grown in parallel, and subjected to identical experimental conditions. At each sample point, two $1-\mathrm{ml}$ samples (one for $\mathrm{CH}$ or other assays, and one for radiolabeling and 2-D PAGE) were taken from one of the fermentations; this culture was designated the "experimental flask." The $2 \mathrm{ml}$ taken from the experimental flask was then replaced from the second parallel fermentation to prevent volume depletion.

Cycloheximide $(\mathrm{CH})$ assay. The $\mathrm{CH}$ was first extracted from a 0.2 $\mathrm{ml}$ aqueous sample with $1.0 \mathrm{ml}$ butyl acetate. An appropriate

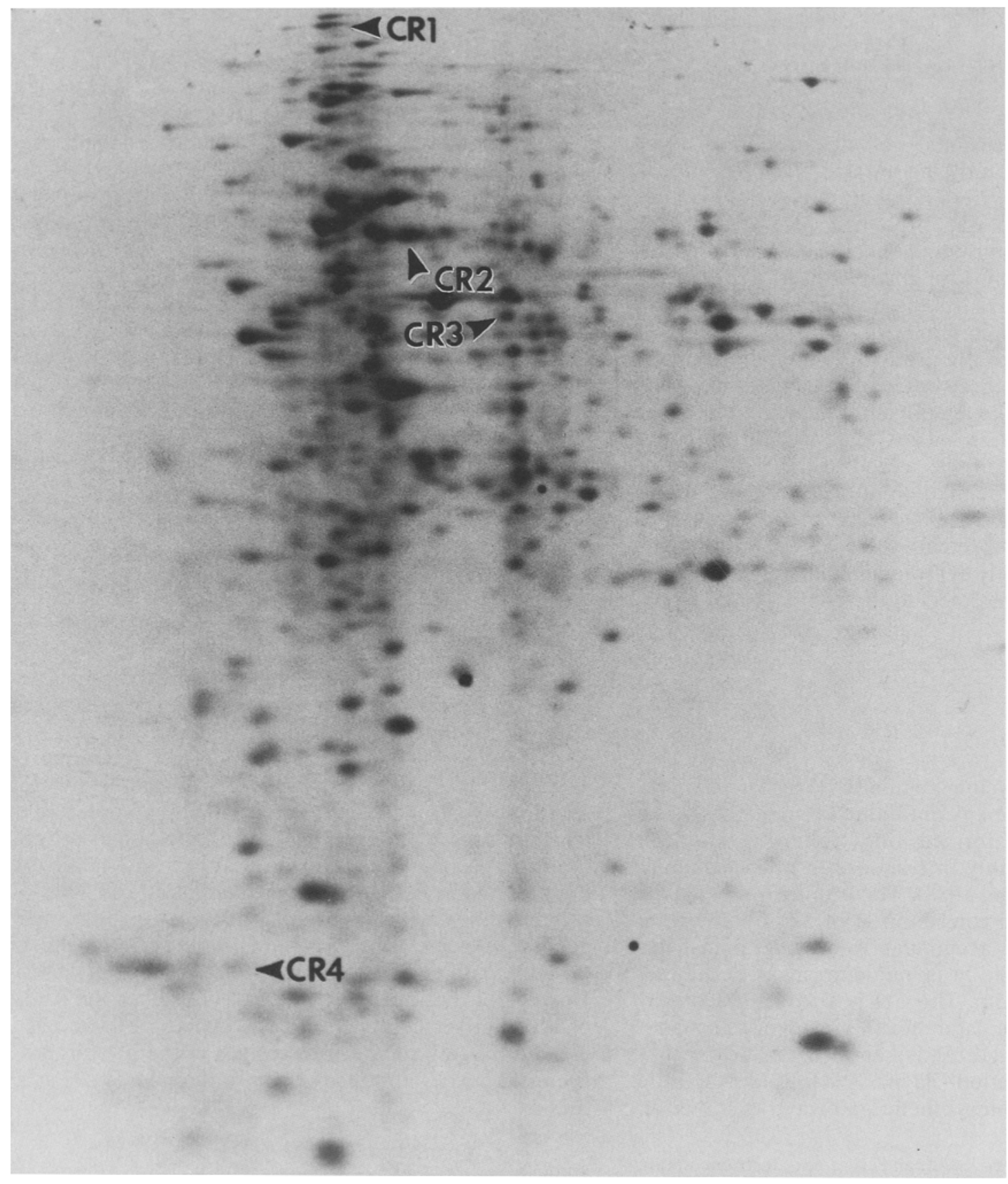

Fig. 1. Two-dimensional electrophoretogram of Streptomyces griseus, UC-2132. The significance of the marked proteins is explained in the text 
amount of the butyl acetate sample was then dried under aeration in a $70^{\circ} \mathrm{C}$ water bath, and the $\mathrm{CH}$ remaining in the tube redissolved in $0.5 \mathrm{ml}$ distilled water. The $\mathrm{CH}$ was then determined by the colorimetric assay of Takeshita et al. (1962).

Radiolabeling of cellular proteins. Radiolabeling of proteins was carried out by placing $1 \mathrm{ml}$ culture in a prewarmed scintillation vial containing $100 \mu \mathrm{Ci}$ of $\left[{ }^{35} \mathrm{~S}\right]$-methionine $(1100 \mathrm{Ci} / \mathrm{mmole}$, Tran ${ }^{35}$ S-Label, ICN Biomedicals, Irvine, Calif., USA). The labeling vials were agitated for $1 \mathrm{~h}$, and the labeling stopped by addition of $10 \mu \mathrm{l}$ of $100 \mathrm{mM}$ L-methionine and $35 \mu \mathrm{l}$ of $100 \mathrm{mM}$ phenylmethylsulfonyl fluoride (PMSF). Incorporation of label was determined by measuring trichloracetic acid (TCA)-insoluble radioactivity in a protocol adapted from Liu et al. (1977). To measure whole cell incorporation, $25 \mu \mathrm{l}$ of the labeled culture was added to $0.5 \mathrm{ml} 10 \% \mathrm{TCA}$, and agitated. The precipitate was collected under suction on a glass fiber filter (Whatman GF/F), and washed with two $0.5 \mathrm{ml}$ aliquots of $10 \%$ TCA and $1 \mathrm{ml}$ of $70 \%$ ethanol. For measurements in 2-D PAGE samples, $5 \mu \mathrm{l}$ of the cell extract was first mixed with $10 \mu \mathrm{l}$ of $1 \%$ bovine serum albumin and $0.5 \mathrm{ml} \mathrm{10 \%} \mathrm{TCA} \mathrm{added.} \mathrm{Incorporation} \mathrm{of} \mathrm{label} \mathrm{was} \mathrm{linear} \mathrm{in}$ stationary phase cultures for at least $1 \mathrm{~h}$.

Sample preparation for 2-D PAGE. A $0.5 \mathrm{ml}$ portion of the labelled cells was spun down and washed with sonication buffer (0.01 $M$ TRIS-HCl, pH 7.4; $5 \mathrm{mM} \mathrm{MgCl}$ ). After washing, the cells were resuspended in $100 \mu \mathrm{l}$ sodium dodecyl sulphate (SDS) lysing solution containing $50 \mathrm{mM}$ TRIS- $\mathrm{HCl}, 2.5 \%$ SDS, $4 \%$ glycerol, and $8 \% \beta$-mercaptoethanol, and placed in a boiling water bath for 5 min. The samples were then cooled on ice, and sonicated in three $5 \mathrm{~s}$ bursts using the micro-tip for the Fisher Dismembrator Model 300 sonicator (Fisher, Pittsburgh, Penn., USA). The samples were again placed on ice, and $2 \mu 1 \mathrm{RNase} / \mathrm{DNase}(1 \mathrm{mg} / \mathrm{ml}$ of each), $20 \mu$ l Nonidet P-40 (Sigma Chemical, St. Louis, Miss. USA), $30 \mu 1$ of $100 \mathrm{mM}$ PMSF, $200 \mathrm{mg}$ urea, and $400 \mu \mathrm{l}$ lysis buffer (9.5 $M$ urea, $1.5 \% \mathrm{pH} 4.0-6.5$ ampholines, $0.5 \% \mathrm{pH} 5.0-7.0 \mathrm{am}$ pholines, $2 \% \mathrm{NP} 40$, and $5 \% \beta$-mercaptoethanol) were added. Samples were then stored frozen until use.

2-D PAGE and autoradiography. O'Farrell 2-D PAGE was carried out essentially using a protocol adapted by Neidhardt and coworkers (Phillips 1988). Isoelectric focusing (IEF) was performed in a Hoefer GT 2 tube electrophoresis chamber (Hoefer Scientific, San Francisco, Calif., USA) at constant voltage of $400 \mathrm{~V}$ for 15 $20 \mathrm{~h}$, followed by $1 \mathrm{~h}$ at $1000 \mathrm{~V}$. The $\mathrm{pH}$ gradient in the IEF gel was imposed with $3.75 \% \mathrm{pH} 4.0-6.5$ carrier ampholytes and $1.25 \%$ pH 5-7 ampholytes (LKB, Bromma, Sweden) in the IEF gel mix. The second dimension SDS electrophoresis was performing using $1.5-\mathrm{mm}$ thick gels in a Hoefer SE 700 slab electrophoresis unit at constant current of $25 \mathrm{~mA}$ per gel for 3.5-4.0 h. First-dimension gels were loaded with a constant amount of TCA-precipitable radioactivity $\left(2 \times 10^{5} \mathrm{cpm}\right)$. Following electrophoresis, the gels were dried (Hoefer slab drier) onto chromatography paper, and exposed to X-ray film (Kodak XAR-5, Rochester, NY, USA) for 9 days. A typical autoradiogram for $S$. griseus is shown in Fig. 1.

Image analysis. The autoradiograms were analyzed using PDQUEST $^{\mathrm{TM}}$ (Protein Databases, Huntington Station, NY, USA) software licensed to the University of Michigan Image Analysis group. Gel images were digitized using an Eikonix (Electronic Pre-Press Systems, Billerica, Mass., USA) scanner, and spots identified using the spot detection program in the software. The relative level of radioactivity and hence the relative level of synthesis of a particular protein was quantified on the basis of the integrated optical density of a spot. The gel images were then visually compared with the autoradiograms, and manually edited to remove spurious spots arising from dust and scratches on the film. Finally, individual protein spots on different gels were matched for comparison. To measure a quantitative difference between two samples, the integrated optical densities of corresponding protein spots on two gels were compared in order to assess the relative amount of radioactivity in each spot. In experiments to assess the reproducibility of this technique, proteins with synthesis levels above $500 \mathrm{ppm}$ had a coefficient of variation of about 30\% (Dykstra 1989).

\section{Results}

As shown in Fig. 2a, addition of $1 \mathrm{mg} / \mathrm{ml}$ of $\mathrm{CH}$ to a producing culture at $72 \mathrm{~h}$ immediately halted further accumulation of antibiotic. Antibiotic addition had no appreciable effect on the glucose consumption rate $(0.47 \pm 0.05 \mathrm{~g} / 1$ per hour in the control vs $0.43 \pm 0.04$ after $\mathrm{CH}$ addition), nor did it significantly affect the overall rate of protein synthesis in the cells (measured by label incorporation into TCA-precipitable material; $1.27 \pm 0.20 \times 10^{6} \mathrm{cpm} / \mathrm{h} \cdot 25 \mu \mathrm{l}$ in the control, vs $1.40 \pm 0.14 \times 10^{6}$ following antibiotic addition). The feedback regulatory effect of $\mathrm{CH}$ addition on its own production cannot therefore be ascribed to any general effect on cell physiology, but appears to be specific for antibiotic synthesis.

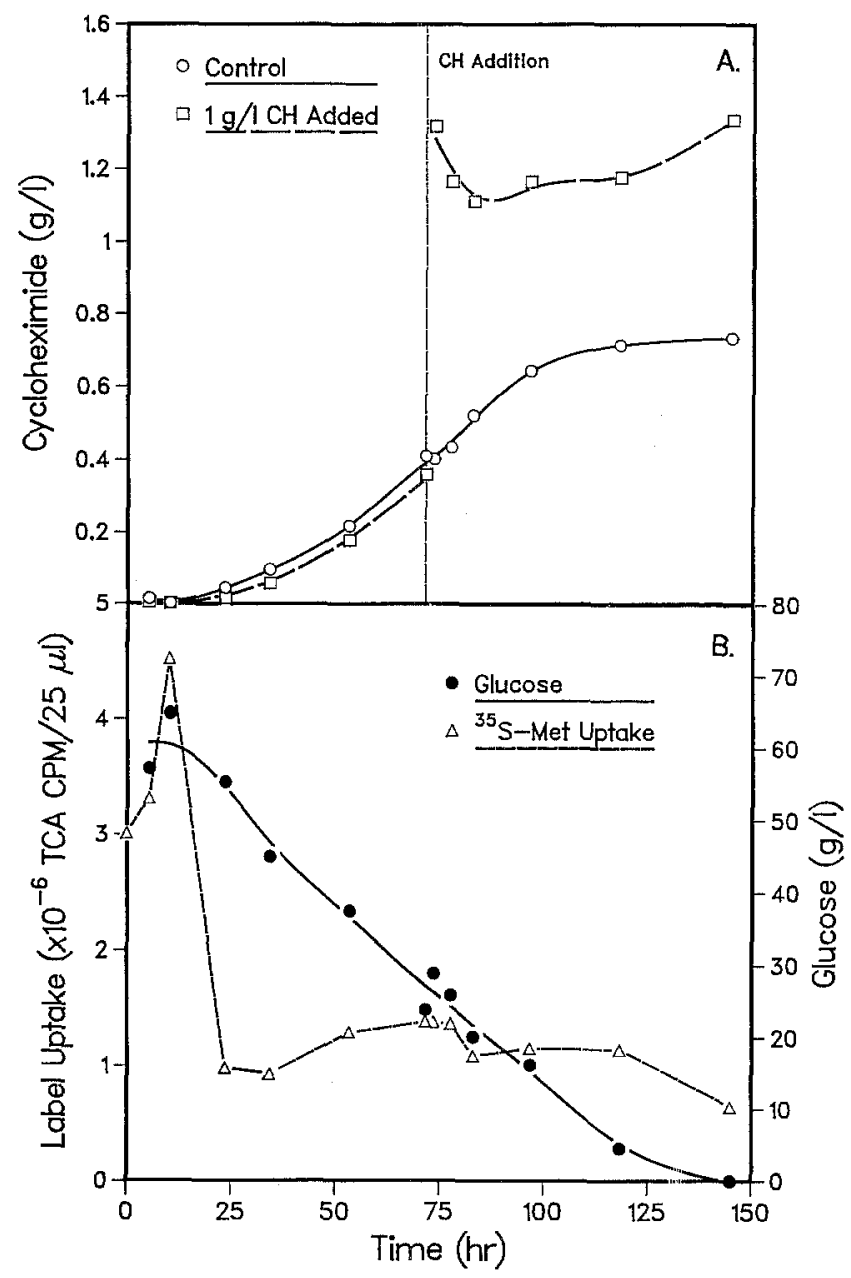

Fig. 2. A Effect opf adding $1 \mathrm{~g} / 1$ cycloheximide $(\mathrm{CH})$ at $72 \mathrm{~h}$ on further antibiotic accumulation. B Glucose consumption and uptake of labeled methionine $\left({ }^{35} \mathrm{~S}-\mathrm{Met}\right)$ into trichloracetic acid (TCA)-precipitable material over the course of a normal batch fermentation 


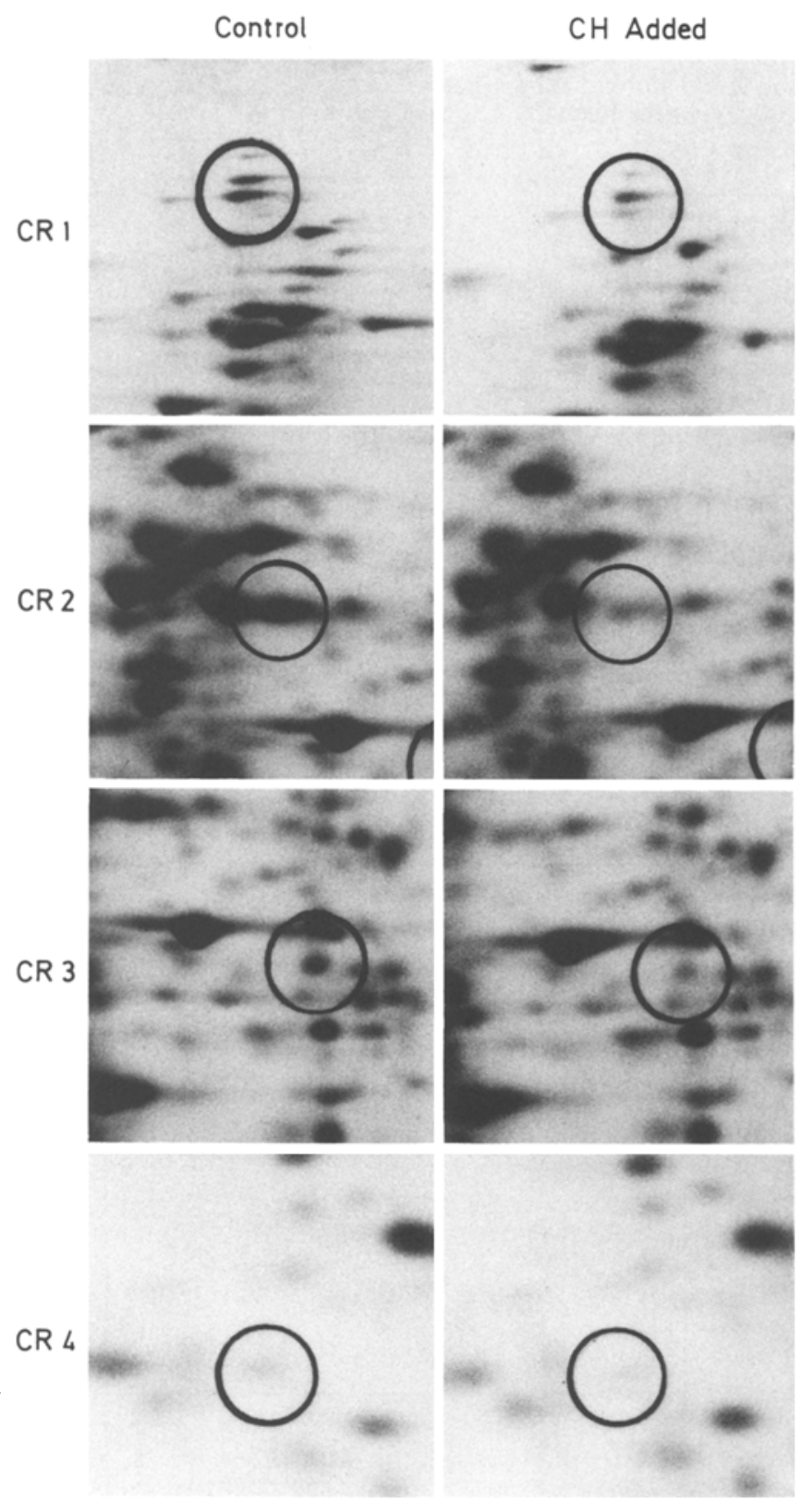

Fig. 3. Effect of $\mathrm{CH}$ addition on synthesis of four proteins: antibiotic addition clearly and specifically reduced the synthesis rate of these proteins

To study the effect of added antibiotic on the intracellular protein profile, whole-cell protein extracts were prepared at various times following $\mathrm{CH}$ addition to a normal, producing fermentation at $69 \mathrm{~h}$, and 2-D electrophoretograms prepared. Figure 3 shows the effect of $\mathrm{CH}$ addition on four proteins $4 \mathrm{~h}$ after addition of the antibiotic (their locations are marked in Fig. 1). It can very clearly be seen that addition of the antibiotic resulted in a substantial reduction in the synthesis rate of these proteins, and Table 1 shows the time course of this effect. It is interesting to note that the effect of $\mathrm{CH}$ on the protein profile is specifically restricted to a small number of proteins. Furthermore, while the reduction in the level of synthesis of proteins CR1 and CR2 re-
Table 1. Time course of the effect of cycloheximide addition on the synthesis of four proteins

\begin{tabular}{lllll}
\hline Protein & \multicolumn{4}{l}{ Fraction of control synthesis rate } \\
\cline { 2 - 5 } & $0 \mathrm{~h}$ & $2 \mathrm{~h}$ & $4 \mathrm{~h}$ & $12 \mathrm{~h}$ \\
\hline $\mathrm{CR} 1$ & $1.38 \pm 0.24$ & $0.19 \pm 0.12$ & $0.31 \pm 0.10$ & $0.22 \pm 0.11$ \\
$\mathrm{CR} 2$ & $0.83 \pm 0.15$ & $0.34 \pm 0.12$ & $0.40 \pm 0.15$ & $0.38 \pm 0.15$ \\
$\mathrm{CR3}$ & $0.77 \pm 0.09$ & $0.60 \pm 0.08$ & $0.35 \pm 0.09$ & $0.64 \pm 0.10$ \\
CR4 & $0.89 \pm 0.32$ & $0.34 \pm 0.09$ & $0.26 \pm 0.16$ & $0.67 \pm 0.14$ \\
\hline
\end{tabular}

Times are given in hours following antibiotic addition. Table values are the ratio of the synthesis rate (in ppm) of each protein in the experimental fermentation to the control fermentation. For each time point, gels were compared for three protein extracts from each fermentation, and differences are significant with at least $95 \%$ confidence from Student's $t$ test. Errors shown are $\pm \mathrm{SD}$

mained relatively constant following $\mathrm{CH}$ addition, the synthesis levels of proteins CR3 and CR4 passed through minima, and again began to approach the control level by $12 \mathrm{~h}$ after antibiotic addition.

In order to determine the growth phase in which these proteins are normally synthesized, their synthesis was followed through the course of a normal batch fermentation. As shown in Fig. 2, the onset of stationary phase was marked by the beginning of significant antibiotic production and a substantial downturn in the overall rate of protein synthesis, while the end of the production phase was marked by the depletion of glucose in the fermentation medium. Other investigators have noted that the cell growth rate is highest during the first $24 \mathrm{~h}$ of the fermentation, with little change in cell mass after 2 days (Kominek 1975a; Payne 1984). As shown in Fig. 4, synthesis of all four of the proteins affected by $\mathrm{CH}$ was very low during cell growth and was significant only after the onset of the stationary phase. Their synthesis decreased sharply following exhaustion of glucose in the medium. Their synthesis is thus specific to the idiophase, concurrent with $\mathrm{CH}$ biosynthesis.

Kominek (1975a) showed that when $\mathrm{CH}(1 \mathrm{mg} / \mathrm{ml})$ was added to the production medium at the beginning of fermentation, further net accumulation of antibiotic was suppressed. However, synthesis of antibiotic still occurred under these conditions, as evidenced by incorporation of label from radioactive glucose into antibiotic. In Fig. 5 is shown the effects of initial $\mathrm{CH}$ addition on the time profiles of the synthesis of the four $\mathrm{CH}$ sensitive proteins. The increase in the synthesis of protein CR1 was delayed by at least $14 \mathrm{~h}$, and the synthesis rate remained somewhat lower than that the control throughout the fermentation. For protein CR2, the synthesis level was not significantly different from the control early in the fermentation, but may have been slightly lower later in the fermentation. For proteins $\mathrm{CR} 3$ and $\mathrm{CR} 4$, initial addition of $\mathrm{CH}$ delayed peak synthesis rates by $12-25 \mathrm{~h}$. It is interesting to note that in each of the experiments described here these two proteins behaved in a co-ordinated fashion; they appeared to be co-regulated. 


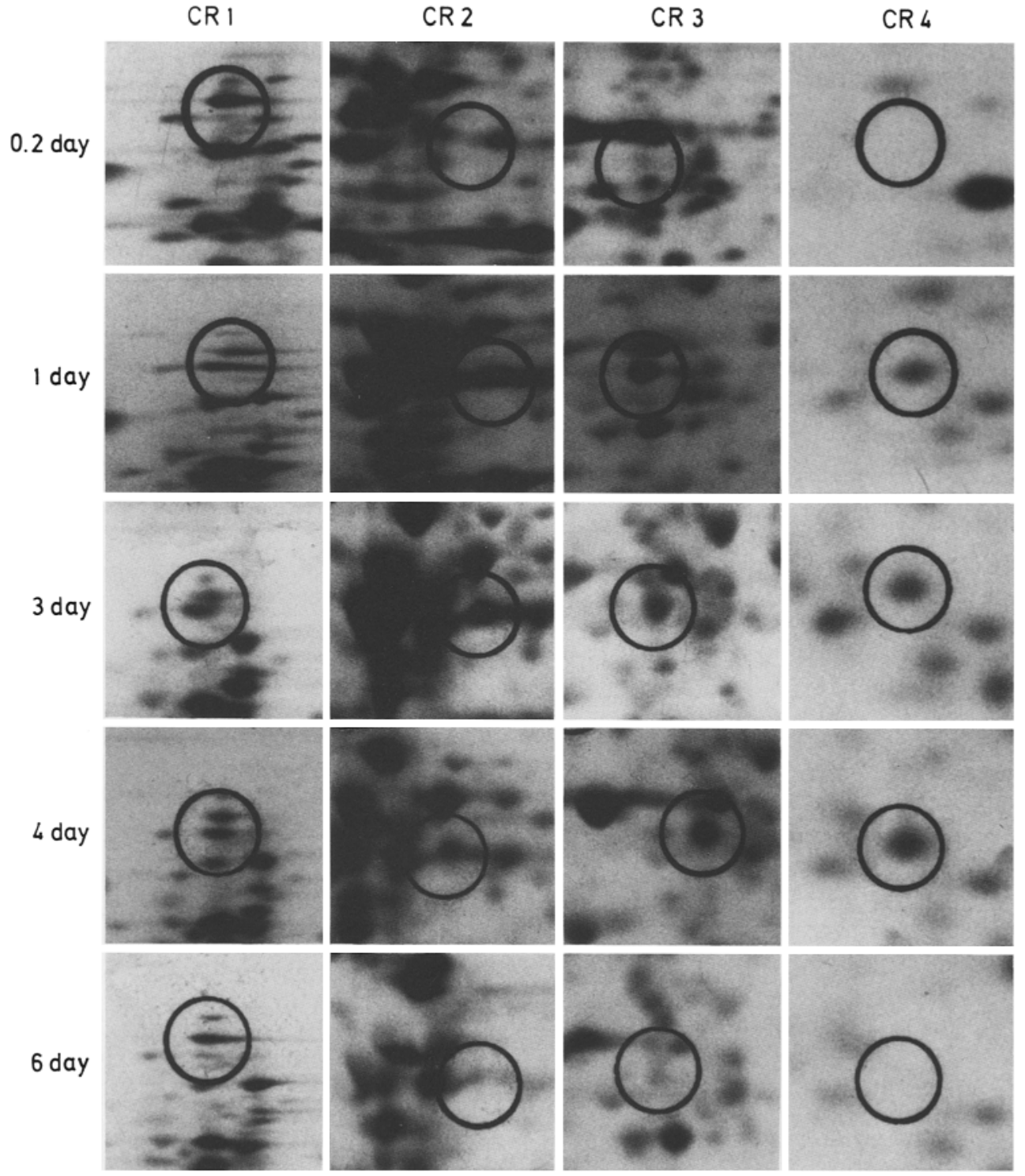

Fig. 4. Normal time profiles for the synthesis of the four proteins repressed by $\mathrm{CH}$; substantial synthesis did not begin until the onset of secondary metabolism, and stopped with glucose exhaustion
As discussed previously, addition of neutral polymeric resin (XAD-4, Rohm and Haas, Philadelphia, Penn., USA) to the fermentation maintains the broth concentration of $\mathrm{CH}$ at a low level $(20-25 \%$ of the control), but results in a roughly twofold increase in the overall production rate of $\mathrm{CH}$, presumably by alleviating the effects of feedback regulation (Wang 1983). This treatment had no ascertainable effect on the synthesis of proteins CR1 and CR2. However, as shown in Fig. 6, addition of resin resulted in an immediate and dramatic increase in the synthesis rates of CR3 and CR4. It also had no immediate effect on the synthesis of any other proteins, although later in the fermentation (at least $6 \mathrm{~h}$ following resin addition) production of several other proteins not seen in the control protein profile increased substantially. The fact that $\mathrm{CH}$ repessed the synthesis of proteins CR3 and CR4, and their synthesis rate (and hence, their concentration) increased under conditions where antibiotic synthesis was also increasing provides additional evidence for the connection between these proteins and $\mathrm{CH}$ produc- tion. It is also interesting to note that, as in the experiment with $\mathrm{CH}$ addition, the response of the synthesis rate to a given stimulus was similar for both proteins. Regulation of their synthesis again appears to be coordinated. Furthermore, their synthesis rates appear to be controlled in some manner at a particular value. In their response to $\mathrm{CH}$ additon and to resin addition, the synthesis rate of both proteins returned to approximately the control value following a substantial perturbation.

\section{Discussion}

In these experiments, we have seen that 2-D PAGE is a very powerful technique for examining the protein profile in relationship to antibiotic production in $S$. griseus. Although very little is known about the biosynthetic pathway for $\mathrm{CH}$, examination of the intracellular protein profile of the producing microorganism can yield significant insight into the regulatory behavior involved in production of this secondary metabolite. 


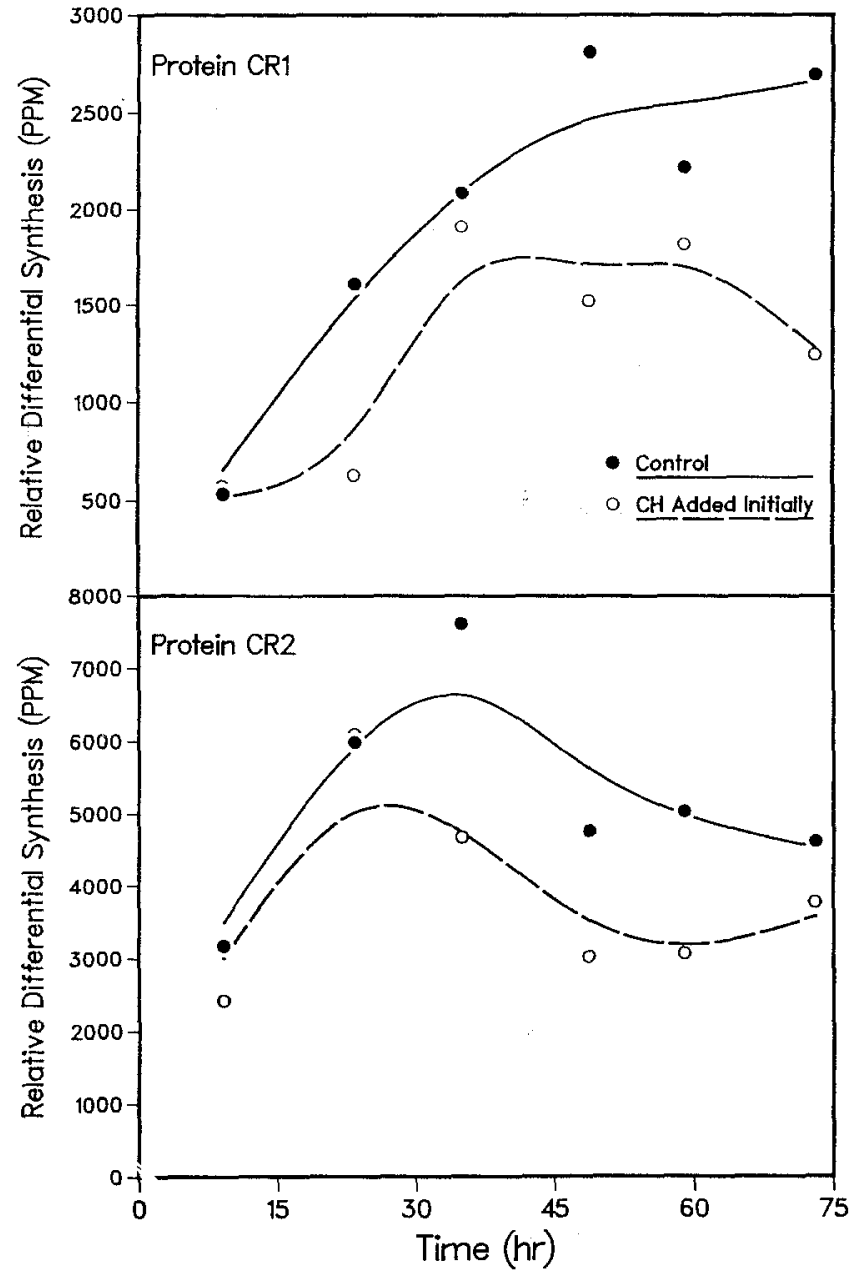

Fig. 5. Effect of initial $\mathrm{CH}$ addition on the time profile for the synthesis rate of the four repressed proteins. $\mathrm{CH}(1 \mathrm{mg} / \mathrm{ml})$ was included in the production medium at the start of the fermentation

It is known that production of $\mathrm{CH}$ is feedback regulated (Kominek 1975a), and computer modeling of the fermentation has suggested that changes in the rate of synthesis of the producing proteins may occur due to feedback repression (Dykstra and Wang 1987). Further evidence of feedback repression rests on the fact that chloramphenicol, and inhibitor of protein synthesis, quickly stops further accumulation of $\mathrm{CH}$. Kominek (1975a) asserted that chloramphenicol had no effect on protein synthesis because of continued glucose uptake by the cells. However, studies of the effect of chloramphenicol on the uptake of radiolabeled methionine clearly show the nearly complete cessation of amino acid uptake into TCA-precipitable material following chloramphenicol addition (Dykstra 1989). If feedback repression were the mechanism of feedback regulation, it might be expected that addition of the antibiotic to a producing culture would specifically depress the rate of synthesis of several of the proteins which were involved in $\mathrm{CH}$ production.

Here, four proteins have been identified whose synthesis is substantially reduced by addition of $\mathrm{CH}$ to a

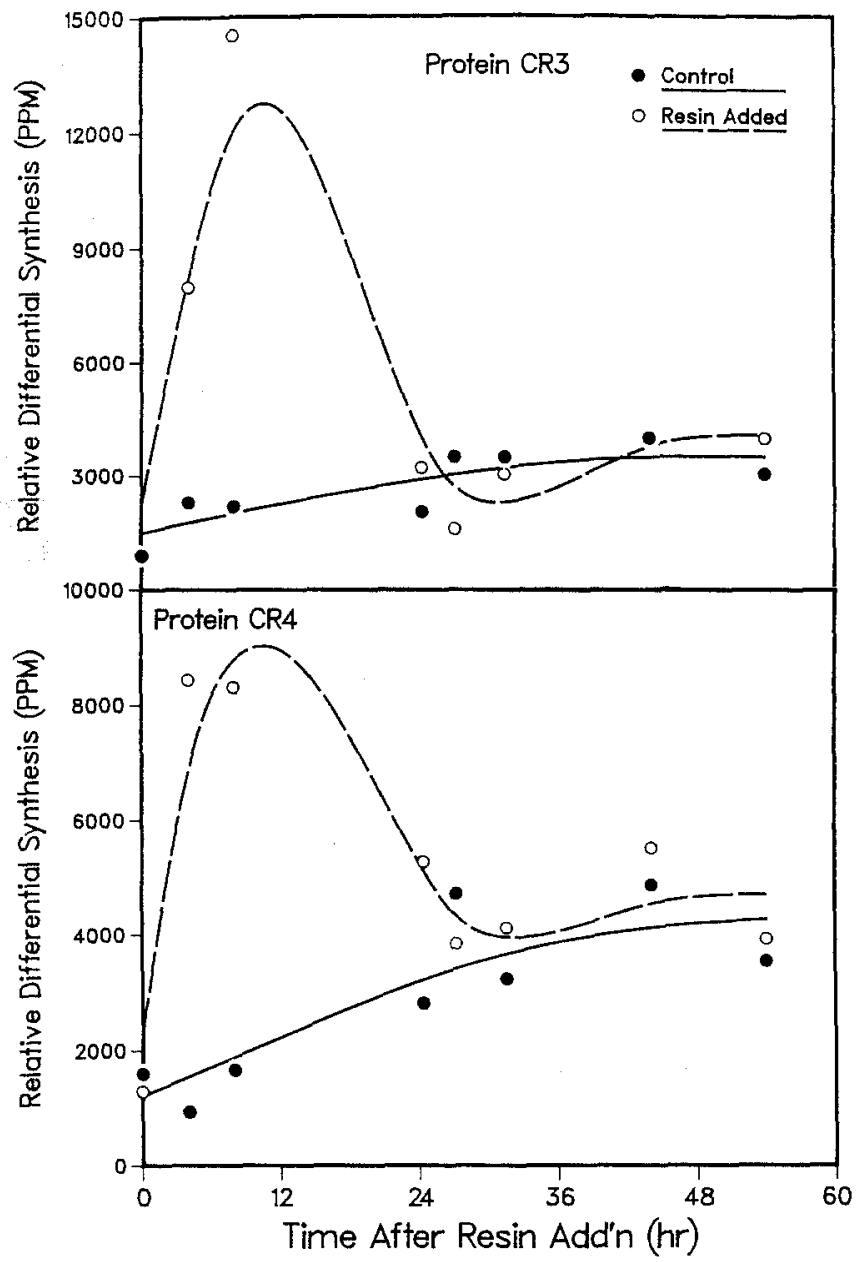

Fig. 6. Time course of the resin effect on CR3 and CR4: the proteins synthesis rate increased to roughly ten times the control rate immediately following resin addition, and later returned to approximately the control level

producing fermentation. Furthermore, the synthesis of these proteins is specific to the idiophase, concurrent with $\mathrm{CH}$ production. This behavior is in accord to that expected if feedback repression plays a significant role in the regulation of antibiotic synthesis. It was also seen that although initial addition of $\mathrm{CH}$ does not prevent synthesis of these proteins, the onset of their synthesis is delayed for all but one protein (CR2). Under these conditions further accumulation of antibiotic is prevented, although it is not clear whether this is because synthesis is completely prevented or because synthesis is induced at a rate sufficient to balance degradation of $\mathrm{CH}$.

The experiments with resin addition showed that a large increase in the synthesis of two of the proteins described above (CR3 and CR4) accompanies resin addition and the concomitant increase in $\mathrm{CH}$ production in the producing strain. Because they are significantly repressed by addition of $\mathrm{CH}$ in a producing fermentation, and because their synthesis rate is increased along with the rate of $\mathrm{CH}$ synthesis when resin is added, it is reasonable to suggest that they are also associated with 
antibiotic production. Further, since their synthesis changes in similar fashion in all experiments performed in this work, it seems likely that these two proteins share very similar regulatory characteristics.

Acknowledgement. We acknowledge the financial support from the National Science Fundation.

\section{References}

Dykstra KH (1989) Intracellular events occurring with on-line product removal in a cycloheximide fermentation. $\mathrm{Ph}$. D. Dissertation, University of Michigan

Dykstra KH, Wang HY (1987) Changes in the protein profile of Streptomyces griseus during a cycloheximide fermentation. Ann NY Acad Sci 506:511-522

Goldman D, Merril CR, Polinsky RJ, Ebert MH (1982) Lymphocyte proteins in Huntington's disease: quantitative analysis by use of two-dimensional electrophoresis and computerized densitometry. Clin Chem 28:1021-1025

Kominek LA (1975a) Cycloheximide production by Streptomyces griseus: control mechanisms of cycloheximide biosynthesis. Antimicrob Agents Chemother 7:856-860

Kominek LA (1975b) Cycloheximide production by Streptomyces griseus: alleviation of end-product inhibition by dialysis-extraction fermentation. Antimicrob Agents Chemother 7:861863

Liu CM, Hermann T, Miller PA (1977) Feedback Inhibition of an antibiotic: Aurodox (X5108). J Antibiot 30:244-251
Neel JV, Rosenblum BB, Sing CF, Skolnick MM, Hanash SM, Sternberg S (1984) Adapting two-dimensional electrophoresis to the study of human germ-line mutation rates. In: Celis JE, Bravo R (ed) Two-dimensional gel electrophoresis: methods and applications. Academic Press, New York, pp 260-306

Neidhardt FC, VanBogelen RA (1987) Protein regulatory gene for temperature controlled proteins in Escherichia coli. Biochem Biophys Res Commun 100:894-900

Payne GF (1984) Enhanced Secondary metabolite production through on-line product removal. Ph. D. Dissertation, University of Michigan

Payne GF, Wang HY (1988) Phosphate feeding to permit growth while maintaining secondary product synthesis. Appl Microbiol Biotechnol 27:572-576

Payne GF (1984) Enhanced secondary metabolite production in situ product removal on the conversion of sugar to cycloheximide by Streptomyces griseus. Arch Microbiol 151:331335

Phillips TA (1988) Two-dimensional polyacrylamide gel electrophoresis of proteins. DNA Protein Eng Technol 1:5-9

Takeshita M, Takahashi G, Okuda T (1962) Studies on Streptomyces antibiotic, cycloheximide. XIII. New spectrophotometric determination of cycloheximide. Chem Pharm Bull (Tokyo) $10: 304-308$

Vanek Z, Puza M, Cudlin J, Dolezilova L (1964) Metabolites of Streptomyces noursei III: incorporation of ${ }^{14} \mathrm{C}$-carbon dioxide into cycloheximide. Biochem Biophys Res Commun 17 (5): $532-535$

Wang HY (1983) Integrating biochemical separation and purification steps in fermentation processes. Ann NY Acad Sci $413: 313-321$ 